\title{
Increased incidence of transient global amnesia during the Covid-19 crisis?
}

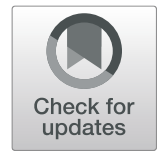

Ralph Werner ${ }^{*}$ (D, Moritz Keller and Johannes C. Woehrle

\begin{abstract}
Since the beginning oft he Covid-19 pandemic we have observed an increased incidence of transient global amnesia, possibly related to emotional stress as a trigger factor.
\end{abstract}

Keywords: Transient global amnesia, Covid-19, Emotional stress, Takotsubo cardiomyopathy

\section{Main text}

The main clinical feature of transient global amnesia (TGA) is an acute anterograde memory disturbance that resolves within $24 \mathrm{~h}$. It often occurs in the context of physical or emotional stress. Its etiology is still a matter of debate: focal hippocampal ischemia, venous congestion, migraine- or epilepsy-like mechanisms, and metabolic stress have been hypothesized [1].

Since the Covid-19 outbreak in Germany at the end of January 2020 we have noticed an increasing number of patients with TGA in our neurological emergency department in a German academic teaching hospital. Between February 1st and May 15th (when a loosening of the preventive restrictions came into effect because of the decline of new Covid-19 infections in Germany) we diagnosed 16 patients with TGA while the average number of patients in the same period over the last 10 years was 9.7 (SD 2.41, 95\%CI 8.3-11.1). One might speculate that the real increase in TGA incidence was even bigger as some patients might have taken distance from presenting to an emergency department in fear of getting infected with SARS-CoV-2 there. Accordingly, many stroke units recently reported lower admission rates of patients with TIA or minor strokes since the beginning of the pandemic [2].

The current TGA patients were slightly older than the more than 200 patients of our single center TGA

\footnotetext{
* Correspondence: r.werner@kk-km.de

Katholisches Klinikum Koblenz-Montabaur, Department of Neurology \&

Stroke Unit, Kardinal-Krementz-Str. 1-5, 56073 Koblenz, Germany
}

registry with an average age of 70.8 vs. 66.8 years; 12 (75\%) were female compared to $58 \%$ in the registry [3]. None of them showed symptoms of Covid-19. Two of the 16 patients suffered their second or third episode of TGA, respectively. One patient, a 86-year-old woman, presented with coincident TGA and Takotsubo cardiomyopathy and was referred to the chest pain unit immediately.

Our hypothesis is that the social distancing during the lockdown, uncertainty concerning the future and not least the fear of getting infected increase the stress level in the community which might trigger TGA [4]. We do not assume that the virus itself causes TGA by an encephalitic autoimmune pathology or direct invasion of the CNS as the clinical features were not different from that of "common" TGA.

For Takotsubo cardiomyopathy, that might share pathophysiological mechanisms with TGA $[5,6]$, it has been reported that it can occur in the context of natural disasters like e. g. earthquakes [7]; the first cases in the context of Covid-19 have been published recently [8-10].

We are very interested to learn if neurologists in other hospitals have made similar observations.

\section{Acknowledgements \\ Not applicable.}

\section{Authors' contributions}

R. W. wrote the manuscript with support from M. K. and J. C. W. All authors discussed the results and contributed to the final manuscript. The author(s) read and approved the final manuscript.

(c) The Author(s). 2020 Open Access This article is licensed under a Creative Commons Attribution 4.0 International License, which permits use, sharing, adaptation, distribution and reproduction in any medium or format, as long as you give appropriate credit to the original author(s) and the source, provide a link to the Creative Commons licence, and indicate if changes were made. The images or other third party material in this article are included in the article's Creative Commons licence, unless indicated otherwise in a credit line to the material. If material is not included in the article's Creative Commons licence and your intended use is not permitted by statutory regulation or exceeds the permitted use, you will need to obtain permission directly from the copyright holder. To view a copy of this licence, visit http://creativecommons.org/licenses/by/4.0/. 


\title{
Funding
}

Not applicable.

\section{Availability of data and materials}

The datasets used and/or analysed during the current study are available from the corresponding author on reasonable request.

\section{Ethics approval and consent to participate}

\author{
Not applicable.
}

\section{Consent for publication}

Not applicable.

\section{Competing interests}

The authors declare that they have no competing interests.

Received: 16 May 2020 Accepted: 25 June 2020

Published online: 16 September 2020

\section{References}

1. Szabo, K. (2014). Transient global amnesia. Frontiers of Neurology and Neuroscience, 34, 143-149.

2. Stellungnahme der Kommission Zerebrovaskuläre Erkrankungen der DGN (2020). Auswirkungen der SARS-CoV-2-Pandemie auf die Versorgung zerebrovaskulärer Erkrankungen. https://www.dgn.org/rubrik-dgn/ stellungnahmen-der-dgn/3919-auswirkungen-der-sars-cov-2-pandemie-aufdie-versorgung-zerebrovaskulaerer-erkrankungen.

3. Werner, R., Ekstrom, A., \& Wohrle, J. C. (2019). Demographic and hemodynamic characteristics of a large cohort of patients with transient global amnesia (TGA). Neurology, 92(15 Supplement), P3.9-P076.

4. Troyer, E. A., Kohn, J. N., \& Hong, S. (2020). Are we facing a crashing wave of neuropsychiatric sequelae of COVID-19? Neuropsychiatric symptoms and potential immunologic mechanisms. Brain Behavior and Immunity. https:// doi.org/10.1016/j.bbi.2020.04.027.

5. Eisele, P., Baumann, S., Noor, L., El-Battrawy, I., Ebert, A., Gass, A., et al. (2019). Interaction between the heart and the brain in transient global amnesia. Journal of Neurology, 266(12), 3048-3057.

6. Erdur, H., Siegerink, B., Ganeshan, R., et al. (2019). Myocardial injury in transient global amnesia: A case-control study. European Journal of Neurology, 26(7), 986-991.

7. Sato, M., Fujita, S., Saito, A., Ikeda, Y., Kitazawa, H., Takahashi, M., et al. (2006). Increased incidence of transient left ventricular apical ballooning (so-called 'Takotsubo' cardiomyopathy) after the mid-Niigata prefecture earthquake. Circulation Journal, 70(8), 947-953.

8. Minhas, A. S., Scheel, P., Garibaldi, B., Liu, G., Horton, M., Jennings, M., et al. (2020). Takotsubo syndrome in the setting of COVID-19 infection. Journal of the American College of Cardiology Case Reports. https://doi.org/10.1016/j. jaccas.2020.04.023.

9. Meyer, P., Degrauwe, S., Van Delden, C., Ghadri, J. R., \& Templin, C. (2020). Typical Takotsubo syndrome triggered by SARS-CoV-2 infection. European Heart Journal, 41(19), 1860

10. Dabbagh, M. F., Aurora, L., D'Souza, P., Weinmann, A. J., Bhargava, P., \& Basir, M. B. (2020). Carrdiac tamponade secondary to COVID-19. Journal of the American College of Cardiology Case Reports. https://doi.org/10.1016/j.jaccas. 2020.04.009

\section{Publisher's Note}

Springer Nature remains neutral with regard to jurisdictional claims in published maps and institutional affiliations. 